2012

\title{
Producing Edible Landscapes in Seattle's Urban Forest
}

Rebecca J. McLain

Portland State University

Melissa R. Poe

Northwest Sustainability Institute

Patrick T. Hurley

Ursinus College,phurley@ursinus.edu

Joyce LeCompte

University of Washington

Marla R. Emery

USDA Forest Service

Follow this and additional works at: https://digitalcommons.ursinus.edu/environment_fac

Part of the Environmental Studies Commons, Food Security Commons, Natural Resources Management and Policy Commons, Nature and Society Relations Commons, Other Political $\underline{\text { Science Commons, Place and Environment Commons, Sustainability Commons, and the Urban }}$ Studies and Planning Commons

Click here to let us know how access to this document benefits you.

\section{Recommended Citation}

McLain, Rebecca J.; Poe, Melissa R.; Hurley, Patrick T.; LeCompte, Joyce; and Emery, Marla R., "Producing Edible Landscapes in Seattle's Urban Forest" (2012). Environmental Studies Faculty Publications. 7.

https://digitalcommons.ursinus.edu/environment_fac/7 


\title{
Producing edible landscapes in Seattle's urban forest
}

\author{
Rebecca McLain $^{\mathrm{a}, *}$, Melissa Poe ${ }^{\mathrm{a}}$, Patrick T. Hurley ${ }^{\mathrm{b}}$, Joyce Lecompte-Mastenbrook ${ }^{\mathrm{c}}$, Marla R. Emery ${ }^{\mathrm{d}}$ \\ a Institute for Culture and Ecology, PO Box 6688, Portland, OR 97228, USA \\ b Ursinus College, Department of Environmental Studies, Collegeville, PA, USA \\ c University of Washington, Department of Anthropology, Seattle, WA, USA \\ d USDA Forest Service Northeast Research Station, Burlington, VT, USA
}

\section{A R T I C L E I N F O}

Keywords:

Green infrastructure

Urban ecosystems

Urban food production

Urban forestry

Urban planning

\begin{abstract}
A B S T R A C T
Over the next decades, green infrastructure initiatives such as tree planting campaigns, and ecological restoration will dramatically change the species composition, species distribution and structure of urban forests across the United States. These impending changes are accompanied by a demand for urban public spaces where people can engage in practices such as gleaning, gardening, and livestock production. This article analyzes the institutional framework that undergirds efforts in Seattle, Washington to normalize the production and use of edible landscapes. We focus attention on the role of grassroots fruit gleaning groups and highlight their bridging function between Seattle's agriculture and forestry policy arenas, creating an entry point for re-conceptualizing urban forests as sites of production. We conclude that a vision of urban forests as providers of goods as well as services may provide a more solid foundation for achieving urban sustainability than the current "hands off" approach to urban forest management. Gleaning and gathering in urban wild and cultivated landscapes provides opportunities for inhabitants to steward public natural resources and interact deeply with nature.
\end{abstract}

(c) 2012 Elsevier GmbH. All rights reserved.

\section{Introduction}

In the past two decades, green infrastructure programs have proliferated in cities across the United States. Initially focused on planting trees, restoring habitat, and developing trails and greenways, green infrastructure programs now include stormwater management projects, such as bioswales, vegetated street strips, and rain gardens. They also include food security projects, such as community gardens, rooftop vegetable gardens, and public orchards. The collective goal of these programs is to create sustainable urban ecosystems through the development of a dense "network of open space, airsheds, watersheds, woodlands, wildlife habitat, parks, and other natural areas" that provide the "vital services that sustain life and enrich the quality of life" (President's Council on Sustainable Development, 1999, p. 64). Urban forests, together with the trees, understory vegetation, and fungi they contain, are key components of this network.

Although some urban forests result from coordinated planning, most are outcomes of a series of largely uncoordinated land use decisions and activities carried out over time by numerous individuals, corporations, non-profit institutions, and public entities. However, whether urban forests are intentionally planned or the

\footnotetext{
* Corresponding author. Tel.: +1 5033316681

E-mail address: mclain@ifcae.org (R. McLain).
}

inadvertent consequence of human activities, the configurations they take are never politically neutral. The distribution of sociopolitical power shapes normative views of the purposes of urban forests. Whose vision dominates affects how urban forests are managed, who uses them, the kinds of activities considered appropriate in them, and, ultimately, their species composition and structure (c.f., Gobster, 2001; Heynen, 2003; Brownlow, 2005; Pincetl, 2010).

In an early text on urban forestry, Moll (1989, p. 14) sets forth a vision of how urban forests differ from rural forests:

Where exactly is the line that separates urban from rural forests? Out at the edge of the suburbs, both forests look alike. You can tell the difference by how the land is used - or not used. Rural forests are valued for products - lumber, firewood, maple syrup, and the like - and for wilderness qualities. The urban forest is valued for house and business sites, urban recreation, and water quality.

While a case can be made that this normative vision of the urban forest as a provider of services rather than products holds true for many United States cities, it is manifestly inaccurate when one looks at the history of urban forests globally. For example, many of Europe's urban forests were established or managed to provide cities and towns with fuel, building materials, game, and livestock fodder (Konijnendijk, 2008). To this day, urban forests in many parts of the world are valued as much for the goods they produce as 
for the services they provide (Konijnendijk and Gauthier, 2006). Exploratory research on urban gathering in Baltimore (Jahnige, 2002), New York City (Emery et al., 2010), Philadelphia (Brody and Hurley, 2010), Charleston (Hurley et al., 2008), and the authors' on-going work in Seattle (McLain et al., 2010; Poe et al., 2011) indicates that even in U.S. cities many people obtain products from urban forests. The assertion that urban forests are important for their services rather than their products thus expresses only one vision of urban forests, a vision that reflects a longstanding bias among urban foresters and planners against allowing activities associated with rural areas, such as agriculture, forestry, and livestock production, in urban areas. However, in the past decade, advocates for urban agriculture have successfully argued in many U.S. cities that food production is an important element of sustainable urban ecosystems. This raises the possibility that treating urban forests as important for both their goods and their services might also be desirable for achieving urban sustainability.

The following case study explores how an alternative vision of urban forests, one in which they are seen as both providers of services and sources of goods, is emerging in the city of Seattle. In describing the emergence of this alternative vision, we focus on the role that organized urban-based fruit harvesting groups have played in sparking changes in policies that influence the types of products available in Seattle's green spaces as well as access to those products. We note that other alternative visions, centered on the use of Seattle's forests for products other than fruit, are also beginning to circulate within broader discussions of the role of public open space in the broader urban food system.

We begin with a description of our methods, followed by an overview of Seattle's planning context. We then describe how Seattle's forest management policies strongly privilege a vision of urban forests as providers of services rather than producers of goods. We contrast this with the city's urban agriculture and food policy arena, where the intersection of food security, urban agriculture, and green development interests has sparked calls for policy reforms that support urban food production. We show that fruit harvesting groups have played a prominent role in promoting development of fruit and nut orchards in city parks and other public spaces. We conclude that these fruit harvesting groups, as well as other urban gathering groups, have the potential to serve as a bridge between the food and urban forest policy arenas, creating an entry point for re-conceptualizing urban forests as sites of production.

\section{Methods}

This case study is based on a review of the City of Seattle's policies, laws, regulations and planning documents related to urban forest management and urban agriculture from the mid-1990s to 2010. Policy and planning documents examined included: City of Seattle Comprehensive Plan, the Seattle Urban Forest Management Plan, Seattle Parks and Recreation Strategic Plan, Seattle City Council Ordinances and Resolutions related to urban forestry and urban agriculture, and Client Assistance Memos providing guidance on urban agriculture and forestry issued by the Seattle Departments of Transportation, Planning and Development, and Public Utilities. We also conducted a review of websites and reports about groups active in fruit harvesting or other types of gathering in Seattle's urban forest. We supplemented the policy and website review with data obtained from semi-structured interviews conducted in 2010 with fifteen community gleaning organizations, urban forest conservation organizations, and with employees of the Seattle City Council and Seattle Departments of
Neighborhoods, Planning and Development, Transportation, and Parks and Recreation.

\section{Results}

\section{Planning context}

Seattle is located on the shore of the Puget Sound in western Washington State (Fig. 1). Roughly 3.4 million people live in King, Snohomish, and Pierce Counties, which together make up the Seattle metropolitan area (U.S. Census Bureau, 2010). The city of Seattle, with an estimated population of 608,000 , is the largest population center within the metropolitan area (US Census Bureau, 2010). About $12 \%$ of the Seattle population falls under the poverty line, and households with children face even greater rates of poverty (City of Seattle, 2009a). Over 14\% of the area's households experienced food hardship in 2010 (Food Research and Action Center, 2011).

Seattle has a land area of $217 \mathrm{~km}^{2}$ (City of Seattle, 2005). The city's long growing season, mild climate, and average annual rainfall of $940 \mathrm{~mm}$ favor the growth of a diversity of plant and fungal species; over 500 vascular plant species and an equal if not greater number of fungi are found in Seattle (Jacobson, 2008). Seattle is home to several Coast Salish Native American communities whose primary land use activities prior to European settlement included salmon fishing, marine shellfish harvesting, hunting, and gathering of native edible plants such as huckleberry (Vaccinium spp.), camas (Camassia spp.), and western hemlock (Tsuga heterophylla (Raf.) Sarg.) (Klingle, 2007; Thrush, 2007; Turner, 1995). Europeans began settling in Seattle around 1850. Since the later 1800s, environmental engineering projects and land use practices, such as dredging, leveling, logging and agriculture, have altered local ecologies (Klingle, 2007), influencing the composition and distribution of plant and fungal species now observed in Seattle's parks and forested areas (City of Seattle, 2007b; Lape et al., 2010). Urban industrial, commercial, and residential development are the major land uses today (City of Seattle, 2007b).

Western hemlock (T. heterophylla (Raf.) Sarg.), western red cedar (Thuja plicata Donn ex D. Don), and Douglas-fir (Pseudotsuga menziesii (Mirb.) Franco), species typical of lowland marine forests in the Puget Sound area, once dominated the area where Seattle is now located. On Seattle's wooded park lands, most of these coniferous forests have been replaced with second growth hardwoods, primarily bigleaf maple (Acer macrophyllum Pursh) and red alder (Alnus rubra Bong.). Many park trees are large mature individuals (City of Seattle, 2000). Non-native understory species such as Himalayan blackberries (Rubus armeniacus Focke), English ivy (Hedera helix L.), and Scotch broom (Cytisus scoparius (L.) Link) are prevalent in many natural areas (City of Seattle, 2000). The street tree population is varied, with approximately 300 different species present in Seattle's streetscapes. Seattle's street tree inventory indicates that in residential areas $26 \%$ of trees are of the genus Prunus (primarily flowering cherries and plums), $17 \%$ are Acer (maples), and $8 \%$ are Crataegus (hawthorns) (City of Seattle, 2010f).

Seattle's Comprehensive Plan (City of Seattle, 2005) guides land use planning and management of private and public land in the city. Subtitled "Towards a Sustainable Seattle", the Comprehensive Plan presents a vision of how Seattle can balance environmental health and economic growth. Initially completed in 1994 to meet the requirements of Washington State's 1990 Growth Management Act, the 20-year Plan is periodically updated to reflect changing views of how the city can meet its sustainable urban growth objectives. The Growth Management Act requires that comprehensive plans contain elements on land use, transportation, housing, capital facilities, and utilities. Seattle added neighborhood planning and economic development elements to its 1994 Comprehensive Plan, 

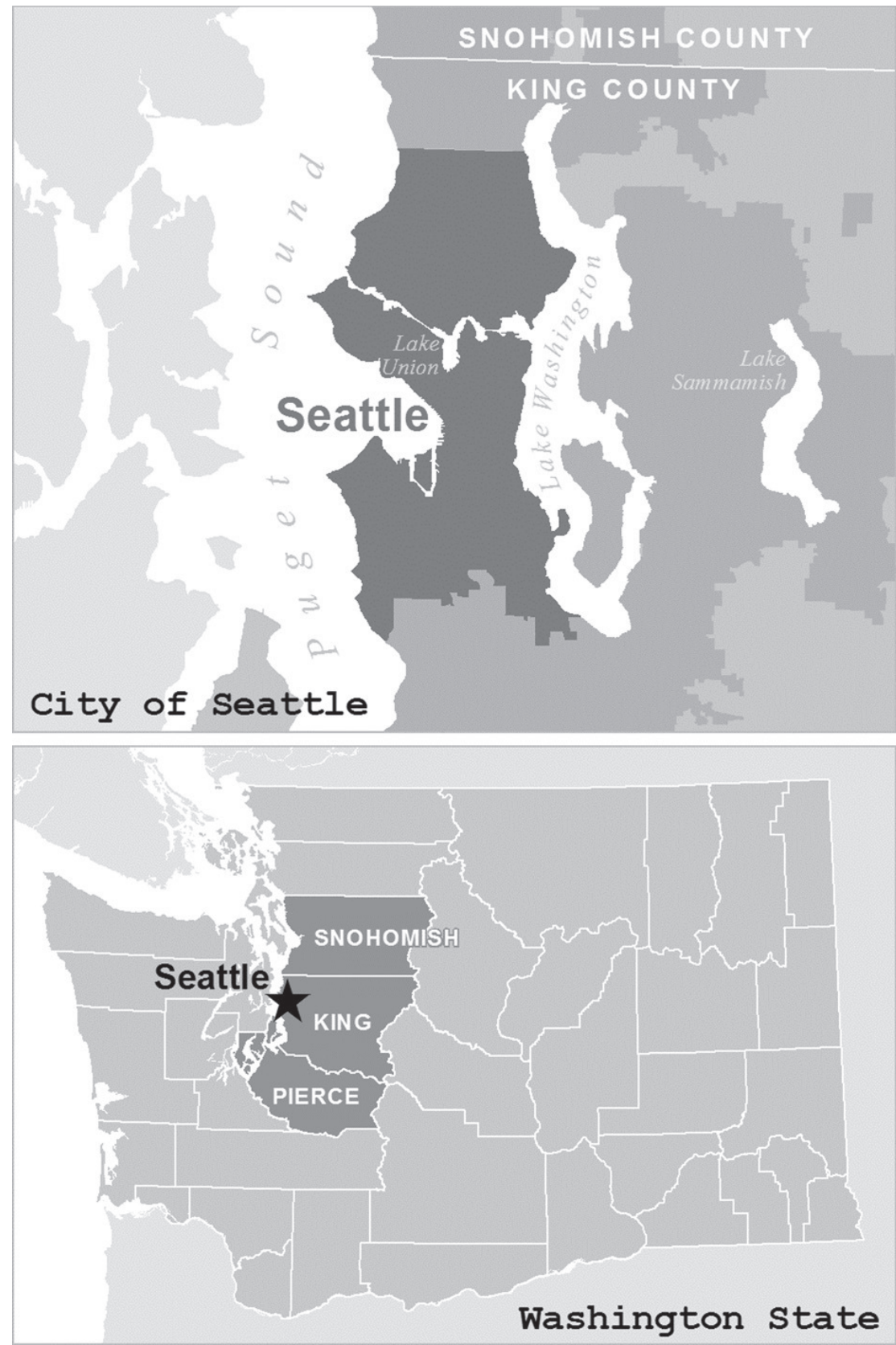

Fig. 1. Seattle metropolitan area.

with community gardens mentioned as an important land use for the city to support. Over time the City has added other elements, including an environmental element in 2000. In 2008 the environmental element was expanded to include a sub-section on trees (City of Seattle, 2009b). In 2009, the City Council passed Resolution 31019 setting forth a guiding framework for achieving urban food system sustainability. Two years later, Seattle's Mayor and City Council declared 2010 "The Year of Urban Agriculture" (City of Seattle, 2010b). In August of 2010, the City revised portions of its land use code (Seattle Municipal Code 23.42.051 and 23.42.052) to expand opportunities for growing plants, farming and raising animals in the city. The objective of the urban agriculture land use code revisions is to create a more just and sustainable food system for urban residents (City of Seattle, 2010d).

\section{Urban forest management in Seattle}

Seattle's Urban Forest Management Plan (City of Seattle, 2007b, p. 1) defines the urban forest located within the official boundaries of the city as "....all trees in the city on both public as well as private property, including street trees, park trees, forested parklands, trees on institutional campuses and trees in many private ownership settings ranging from parking lots to back yards." The plan estimates the number of trees in Seattle's urban forest at a minimum of 1.4 million. This figure refers to trees located within the city's official boundaries, and includes trees in all land ownership and use categories. Approximately half a million trees grow on privately held land, which occupies $74 \%$ of the City of Seattle's land area. According the Seattle's comprehensive plan (2005), most of 
the privately held land consists of single family (64\%) and multifamily ( $9 \%$ ) residential properties. About $10 \%$ of the city's privately held land is categorized as mixed use/commercial, $7 \%$ is considered industrial, and the rest is vacant or of unknown use. The City of Seattle manages about 3237 ha of public land spread across 33 different habitat types. Seattle's forested public lands include streetscapes, developed parks, and wooded parklands. An assessment of Seattle's urban forest sustainability in 2000 found that the city has 125,000 street trees, 90,000 trees in developed park areas, and over 500,000 trees in forested parkland (City of Seattle, 2000). The same study estimated that the City has 2752 ha of woodland canopy, of which nearly half is in the city's park system.

Seattle's urban forest is heavily shaped by the city's early investments in green space planning. The first comprehensive proposal to manage a system of urban forests was put forth in 1892 (Morgan, 1979). In 1903, the city hired the Olmsted firm to design a network of treed boulevards, developed parks, playgrounds, and greenbelts structured so that every resident would be located no more than $.8 \mathrm{~km}$ (half a mile) from green space (Dooling et al., 2006). The resulting park and boulevard system, much of which was completed by 1914, is the heart of Seattle's public urban forest. This system, which is known as the Olmsted Vision, sought to balance aesthetic and recreational values.

In the seven decades following its early and substantial investment in the Olmsted Vision, the city devoted relatively few resources toward expanding or maintaining its green space network (Dooling et al., 2006; City of Seattle, 2007b). Not until the early 1990s did support for green space investment return to the level that had made implementation of the expansive Olmsted Vision possible. Passage of an Open Space bond measure in 1989 marked the beginning of this new era in sustained civic interest in Seattle's green space network. Dooling et al. (2006, p. 312) refer to this as the "Pocket Parks in a Global City" period, arguing that a significant shift occurred in how the city views and manages green space.

Whereas the Olmsted vision promoted a sense of nature based on aesthetic value, the Pocket Parks in a Global City period promotes a functioning of nature based on a scientific understanding of ecological systems. The 1903 Olmsted plan is revisited, revised and expanded to reflect its application in a more densely settled urban area. While serving the recreational needs of Seattle's citizenry remains an important goal, a conservationist approach also infuses park management.

Dooling's analysis focuses on Seattle's parks rather than its urban forest. However, we argue that the shift in how the city's parks were perceived was accompanied by a similar shift in how its urban forest writ large is perceived. Specifically, rather than seeing park and street trees as amenities and therefore luxury items, beginning in the early 1990s, the City began to conceptualize trees as infrastructure assets and essential elements of a sustainable urban ecosystem. This change is most clearly articulated in the city's decision in 1994 to allocate funds from the city's Cumulative Reserve Fund, a fund reserved for infrastructure investments, to support forest restoration activities in the city's parks (City of Seattle, 2007b).

A street tree health assessment conducted by the Seattle Department of Transportation in 1994 found that 42\% of the city's street trees were in poor health and vulnerable to pests, disease, and wind damage (City of Seattle, 2007b). The prevalence of aging tree populations along city streets and in parks posed a substantial hazard to residents and their property. In response to this threat and to growing concern about the widespread removal of trees for residential and industrial development, the city began working with several non-profit organizations to improve the health of Seattle's public urban forest, limit the removal of trees on private and public land, and expand the city's forest management capacity (City of Seattle, 2007b).

In 1994, the City of Seattle established an Urban Forest Coalition to coordinate tree-related programs across the city departments with responsibilities for protecting or managing trees and other vegetation (City of Seattle, 2007b). Since the mid-1990s, the Urban Forest Coalition has commissioned baseline data collection for Seattle's urban forest, led efforts to develop Ordinance 120410, Seattle's municipal tree protection ordinance, and spearheaded the development of Seattle's 2007 Urban Forest Management Plan. In 2007, the Urban Forest Coalition convened the Emerald City Task Force to provide recommendations for strengthening Seattle's tree protection regulations (City of Seattle, 2007a). Two years later, the City Council passed Ordinance 123052, creating a multi-stakeholder Urban Forest Management Commission to advise the Mayor and City Council on tree protection policies.

Since the mid-1990s, the City of Seattle has implemented numerous urban green space improvement programs. These programs initially focused on park restoration and street-tree plantings, but now include conversion of impervious road edges to pervious surfaces so as to improve stormwater drainage (Nicholas, 2002). Seattle residents' support for such programs is evidenced by the passage in 2000 of Ordinance 120024 , the $\$ 198.2$ million Pro Park Levy, and in 2008 of Ordinance 122749, the \$146 million Parks and Green Space Levy. Both levies provided funding for green space acquisitions and restoration activities. In 2006, Seattle voters approved Resolution 30915, the transportation-oriented Bridging the Gap Levy. This levy included funds for planting 8000 new trees and pruning 25,000 existing trees along Seattle's street planting strips (City of Seattle, 2010a). In 2004, the City of Seattle and Cascade Land Conservancy formed the Green Seattle Partnership, a 20-year public/private venture to invest in Seattle's public forestlands. This partnership is intended to enhance the city's livability through green infrastructure improvements and citizen participation in stewardship (Green Seattle Partnership, 2006).

\section{Visions of Seattle's urban forest}

The visions that help shape the species composition and structure of Seattle's urban forests can be identified through an exploration of the plans, policies, and laws emanating from the city commissions and departments most directly involved with managing the city's trees. These include the Urban Forestry Commission, the Department of Planning and Development, Seattle Parks and Recreation, Seattle Department of Transportation, and the Department of Neighborhoods.

\section{The Urban Forestry Commission's vision}

The city's Urban Forestry Commission's vision is most clearly reflected in Seattle's 2007 Urban Forest Management Plan which lays out the city's goals and a set of actions for restoring the city's public forests and to preserve, maintain, and plant trees throughout the city. The Plan is based on Clark et al.'s (1997:20) model of urban forest sustainability, a model whose second principle is "Urban forests primarily provide services rather than goods". In crafting Seattle's Urban Forest Management Plan, its developers drew heavily on an ecosystem analysis conducted in 1999 that used CityGreen, a forest valuation software package that estimates the monetary value of urban trees and green spaces (City of Seattle, 2007b). Modeled values include energy efficiency, stormwater runoff, air pollution removal, carbon storage and sequestration, water quality, and landcover patterns. Social, cultural, and economic values, including those that might be derived from urban forest products are not part of the CityGreen model. The plan has little to say about understory vegetation and is concerned primarily 
Table 1

Values of Seattle's urban forest listed in the 2007 urban forest management plan.

\begin{tabular}{|c|c|c|c|c|}
\hline Ecological values & Quality of life values & Health and safety values & Economic values & Socio-cultural values \\
\hline Wildlife and bird habitat & Livability & Reduction in crime rates & Increase in property values & $\begin{array}{l}\text { Environmental } \\
\text { learning opportunities }\end{array}$ \\
\hline Shade to cool streams & Aesthetics & Reduction in health care costs & Higher shopping frequency & Connections to nature \\
\hline Rainwater interception & $\begin{array}{l}\text { Access to } \\
\text { recreational facilities }\end{array}$ & Traffic calming & Higher office occupancy rate & Connections to people \\
\hline Erosion reduction & & Separation of pedestrians from vehicles & & \\
\hline Air quality improvements & & Encourages people to exercise & & \\
\hline Water quality improvements & & & & \\
\hline Greenhouse gas reduction & & & & \\
\hline
\end{tabular}

with increasing the city's tree canopy coverage from $18 \%$ to $30 \%$ of Seattle's land area by 2037.

That the Plan envisions Seattle's urban forest as first and foremost a provider of services is made clear in the introduction, which states, "Unlike timber forests that are grown primarily to produce forest products, urban forests provide services such as air and water quality improvement [bolding in original document]". The Plan's section on urban forest values does not mention products. Although the plan emphasizes environmental services, it also acknowledges that "social services", such as quality of life, health and safety, economic, and socio-cultural values are important services of Seattle's urban forest (see Table 1). However, nowhere does the Plan envision that Seattle residents might value the fruits, nuts, berries, medicinal plants, or mushrooms found in urban forests. Yet, our data (Poe et al., 2011) and a quick survey of Internet website, blogs, and newspapers reveal that all of these activities take place within Seattle's urban forest (Lennebacker, 2006; Thomson, 2007; Tsong, 2007; Poe, 2011, 2010).

\section{The Parks and Recreation Department's vision}

The planning documents and regulations governing vegetation use and management in Seattle's Parks and Recreation system historically have envisioned the urban forest as a provider of services rather than goods. Section 12.070 of Seattle's Park and Recreation Code reflects this philosophy when it states,

"It is unlawful for any person except a duly authorized Department of Parks and Recreation or other City employee in the performance of his or her duties, or other person duly authorized pursuant to law, to remove, destroy, mutilate or deface any ... shrub, tree, ... plant, flower, ... in any park."

Violators of this law are subject to a fine of up to $\$ 5000$ or imprisonment of up to one year or both. Seattle's anti-product management approach for its parks and recreation system dates back to the Olmsted Vision era, when supporters of hunting and wood harvesting in the city's newly established parks lost out to proponents of parks as playgrounds and aesthetic backdrops (Klingle, 2007). The management contradictions inherent in the blanket prohibition against removing plants, which has been interpreted to include plant parts as well as whole plants, are illustrated with the example of Himalayan blackberries ( $R$. armeniacus Focke), an invasive species found in most of Seattle's wooded parks. Although picking blackberries in city parks and along city-owned trails is a popular summer activity for many Seattleites, it is a violation of the law. Ironically, the eradication of Himalayan blackberry is a vegetation management priority and the city has gone to considerable expense to remove it.

Seattle Parks and Recreation's anti-production orientation, however, has never been entirely cut and dried, and is rapidly becoming much less so. Nearly a third of Seattle's 73 public community gardens are located in developed parks and efforts to restore heritage fruit orchards or establish new public orchards have recently been undertaken in several parks. The Seattle Parks Fruit
Tree Stewardship project aims to improve urban forests, increase forest canopy, and nurture existing fruit trees on public land. In spring 2011, the Seattle Parks and Recreation Department established a Parks Urban Food Systems web page (City of Seattle, 2011b) to coordinate its urban food system programs and provide opportunities for urban residents to connect with the natural world, obtain fresh fruit and vegetables, and increase environmental stewardship through food production.

\section{Seattle Department of Transportation's vision}

The Seattle Department of Transportation, another city department with extensive management authority over the street tree element of the urban forest, also does not envision the city's street trees as sources of products for urban dwellers. The Seattle Department of Transportation has maintenance responsibilities through its Urban Forestry program for roughly 35,000 street trees while adjacent property owners are responsible for maintaining another 95,000 (City of Seattle, 2010e). According to the street use provisions of the Seattle Municipal Code (15.42.050), only species approved by the Seattle Department of Transportation can be planted on street planting strips. Three species whose fruits are commonly eaten in many parts of the United States - apples (Malus spp.), cherries (Prunus spp.), and pears (Pyrus spp.) - are on the prohibited species list. The rationale for prohibiting these species is that their fruits are likely to fall on the sidewalk and increase the risk of pedestrian injuries (City of Seattle, 2010g). City ordinance 90047 requires property owners adjacent to street planting strips to obtain permits from SDOT to plant and prune trees in these strips. Property owners are also responsible for maintaining the trees, including watering, mulching, and pruning (City of Seattle, 2010e). These requirements provide strong disincentives for property owners to plant trees.

\section{Seattle Department of Neighborhoods' vision}

Between 1996 and 2010, the Seattle Department of Neighborhoods, which seeks to strengthen ties between neighborhoods and local government, provided trees and funding for neighborhood street-tree plantings and other urban greening projects throughout the city. Initially the Department envisioned street trees as providers of environmental services. However, the Department recently initiated projects indicative of a shift toward a vision of urban forests as sites of food production. The first shift came in 2009, as the Seattle Department of Neighborhoods' Tree Fund program worked with Earthcorps, an environmental restoration oriented non-profit group, to implement a pilot project to help meet the City of Seattle's tree canopy goals. As an incentive, the program offered participants of the Tree Fund program one free fruiting cherry or apple tree to plant in their private yards (City of Seattle, 2010c). The fruit tree give-away was so popular that in 2010 the Trees for Neighborhoods program invited households to apply for up to four free trees to be planted either in private yards or street planting strips. Acceptable species for planting in the street strip included serviceberry (Amelanchier arborea) and dogwood (Cornus 
x 'Venus'), which produce lesser-known edible fruits. Italian plums (Prunus spp.), however, were available only for private yards. Fruiting tree species with commonly known edibles, such as apples (Malus spp.), cherries (Prunus spp.), and pears (Pyrus spp.) were not offered in 2010 and remain prohibited in street planting strips. The program was transferred to Seattle Public Utilities in December 2010. A second example of the Department of Neighborhoods' shift toward an integrated vision of urban forests as producers of food is the 2011 small grant awarded to the community to create the Beacon Food Forest (City of Seattle, 2011a). The Beacon Food Forest is based on permaculture principles of integrated agro-forestry woodland food systems. It will be located on Seattle Public Utilities lands, overseen by the Department of Neighborhoods, and run by the community. The goals of this project are to provide a local and resilient food source; enhance ecosystem services such as soil enrichment, manage water runoff, improve air quality and create carbon storage; and to empower community connections.

Movement toward normalizing edible landscapes in Seattle's urban forest

The Seattle Parks and Recreation Department's recognition of fruit production as a legitimate management objective for wooded areas and developed parks, and the Seattle Department of Neighborhood's discovery that fruit trees can be used as incentives for city dwellers to plant trees in private yards are closely linked to the growing visibility and power of Seattle's urban agriculture and food policy networks. Relocalizing food production within Seattle's boundaries is a primary aim of these networks, whose roots date back to the early 1970s when the Seattle City Council authorized the Parks and Recreation Department to develop a community garden program on city-owned vacant land (City of Seattle, 2011c). Over the next decade Seattle developed a thriving system of cityowned community gardens known as P-Patches. At present there are 73 P-Patches in Seattle, comprising about 9.3 ha of land, and gardened by 2056 households. Of these, 23 gardens are located in city parks (City of Seattle, 2011c). The program is administered by the Seattle Department of Neighborhoods in collaboration with the PPatch Trust, a non-profit organization whose vision is to encourage community-building by giving people a chance to garden together and learn from each other. One of the key values the P-Patch program aims to promote is access to healthy, organic and culturally appropriate foods to Seattle residents. About thirty P-Patches maintain plots for donations to local food banks through the "Lettuce Link" program.

Lettuce Link (Solid Ground, 2011b), a program of the not-forprofit, Solid Ground, was initiated in 1988 to provide low-income families in Seattle with fresh and organic produce and seeds, as well as gardening information. Lettuce Link staff and volunteers coordinate regular pick-ups from participating P-Patch gardens. This food is then distributed to two dozen food providers in the city. A number of P-Patches have either incorporated fruit trees into the gardens' communal spaces or are adjacent to small orchards maintained by P-Patch gardeners or other community groups. These fruit trees provide an additional food source that Lettuce Link accesses. In fact, the emergence of Seattle's contemporary fruit gleaning milieu can be traced to the Lettuce Link program, whose director organized the harvest of about 500 pounds of fruit from privately owned fruit trees in one of Seattle's neighborhoods in 2005.

Lettuce Link's successful experience with neighborhood fruit gleaning in 2005 spawned Community Fruit Tree Harvest (CFTH) (Solid Ground, 2011a), a city-wide program also administered by Solid Ground, as well as City Fruit, (discussed below) and at least four neighborhood-specific fruit gleaning groups. In collaboration with CFTH, Lettuce Link/Solid Ground produced "Gather It!" a guide to organizing urban fruit tree harvests (Solid Ground, 2009). CFTH's first coordinator, Gail Savina, describes the program as a "fruit sharing" project in which fruit that goes un-harvested is instead picked and delivered to food providers serving city residents in need. CFTH relies on volunteers to scout for fruit trees, provide fruit trees for harvest, harvest and deliver fruit, and store fruit gathering equipment. Fruit is generally gathered twice a week during the active growing season, and distributed to more than sixty food providers. Started in 2005 to serve one neighborhood, by 2009 CFTH volunteers harvested and distributed more than 19,600 pounds of apples, pears and plums throughout the city, and the other fruit gleaning groups harvested an additional 10,000 pounds.

These efforts in harvesting edible landscapes notwithstanding, CFTH and most of Seattle's other gleaning groups do not emphasize fruit trees as a component of the urban forest in their mission and vision statements. One important exception is City Fruit (2011), started in 2008 by former CFTH coordinator, Gail Savina. City Fruit highlights the value of fruit trees - viewed as the "urban orchard" - to the urban forest canopy in its mission to "promote the cultivation of fruit in urban landscapes, build community and protect the climate." Its goals include urban tree canopy preservation, encouraging tree stewardship, expanding neighborhood capacity to harvest fruits, developing fruit preservation capacity, and building connections between groups through fruit tree planting, stewardship, harvesting, and fruit preservation activities. City Fruit sponsors classes on pruning, fruit preservation and pest control, and has produced a series of quick reference guides on topics including fruit tree care, identification and control of common fruit tree pests, and fruit drying. City Fruit also hosts a fruit mapping project, where residents are encouraged to contribute to a "grassroots inventory" of Seattle's fruit trees by providing information to a computer-based mapping program.

By collaborating with other agencies and organizations interested in the maintenance and harvest of the city's fruit trees, City Fruit supports city residents interested in fruit tree care and fruit gleaning. For example, City Fruit brings together volunteers from Seattle Tilth, Plant Amnesty, and the Seattle Tree Fruit Society and matches their expertise in fruit tree and plant care with community groups interested in stewarding trees in public parks and P-Patches. In 2010, City Fruit initiated a Fruit Tree Stewardship program to train and encourage community investment in fruit tree maintenance on publicly owned property. The Fruit Tree Stewards program indicates that urban environmental stewardship is taking place across wild and cultivated natures on both private and public property in Seattle.

These collaborations foster dialogue between food policy and urban forestry advocates, and further blur perceptual boundaries between wild and cultivated areas. For example, City Fruit and collaborating organizations offer pruning classes at historic Piper's Orchard, which is located in Carkeek Park, a Seattle Park natural area best known for its run of wild salmon, forested hiking trails, and bird-watching opportunities. Fruit-oriented groups also contribute to debates that have brought about changes to policy governing public green space use. In 2009, pressure from urban agriculture and food security advocates resulted in the Seattle Department of Transportation modifying its regulations to allow property owners to plant vegetables, perennials and other edibles in adjacent street planting strips without obtaining a permit (O'Hagan, 2009). City regulations still prohibit the planting of fruiting varieties of cherry (Prunus spp.), apple (Malus spp.), and pear (Pyrus spp.) and require a permit for other tree plantings. However, local fruit production advocates and fruit tree stewardship groups have persuaded the Seattle Parks and Recreation Department to allow neighborhood groups to establish public orchards, "food forests" and "edible hedges" in several city parks. Projects funded through the Parks and Green Space Levy's 2010 Opportunity 
Fund included preservation of a historic orchard and acquisition of land to create a permaculture-inspired edible park.

\section{Conclusion}

Seattle's urban forest management plan follows a framework widely used by municipal forestry programs in the United States. This framework envisions urban forests primarily as service providers rather than as sources of goods. This narrow vision of the urban forest historically has been reflected in the policies of the Seattle Parks and Recreation Department and the Seattle Department of Transportation, which together exercise management authority over two-thirds of Seattle's urban forest. The urban forest plan is based on a forest valuation model that fails to incorporate the socio-cultural, psychological, and economic values associated with the gathering and use of urban forest products for food, medicine or other cultural values. We currently lack scientific data on the social and ecological dimensions of gathering activities in urban forests. Studies of gathering in rural areas, however, suggest that gathering can be a sustainable practice depending on the confluence of many factors, including tenure rights and responsibilities, the degree to which products enter into global market systems, the rates of regrowth relative to removal rates, and pressures from competing land uses (Laird et al., 2010).

Our case study indicates that the notion that urban forests might serve as spaces where people engage in productive forest practices, such as gathering, gleaning, and livestock production, is rapidly gaining political traction in Seattle. Fruit harvesting groups, many of which have their roots in the food security movement, have taken a lead role in opening up previously closed public spaces to fruit production. They have also served as a link between the "farm" and "forest" policy arenas, leading to an emerging view of the city as an agroecological landscape where urban forests and agriculture coexist. While visions of the purpose and value of the urban forest and, more broadly, urban green space, are clearly in flux, those visions are still quite restricted and not unified across municipal departments governing urban vegetation. For the most part, the notion that forests might be sources of goods is being applied to private yards, developed parks, vacant lots, street planting strips, and more recently, public lands with remnant orchards. Additionally, the goods that are being constructed as "appropriate" to harvest in these limited spaces of urban forests are edible fruits, nuts, and berries, mostly from introduced species. Heavily wooded areas and wetlands are still deemed "off-limits" as are non-edible products and products other than fruits and nuts (i.e., leaves, barks, cones, seeds, flowers, grasses, reeds, moss, and fungi).

Excluding gathering as a legitimate activity in urban forests presents a number of challenges: (1) it creates confusion about what kinds of plant material are acceptable to remove (invasives, tree fruits, berries?) and who can do so; (2) it criminalizes what are often otherwise benign gathering activities occurring on public land; (3) it adversely impacts lower-income and food-insecure individuals who may use urban forests products to meet some of their nutritional and medicinal needs; (4) it reduces the urgency for land managers to avoid using toxic herbicides and other chemicals in vegetation management; and (5) it fails to create incentives for gatherers, who often possess sophisticated local environmental knowledge, to become involved in broader urban forest stewardship initiatives. In light of what is at stake, we identify an alternative view of urban forests as places where people inhabit nature through the production of edible landscapes. Gleaning and gathering urban wild and cultivated food provides opportunities for urban inhabitants to steward public natural resources and interact deeply with nature. Seattle's recent policy shifts offer an exciting new laboratory where social scientists, urban ecologists, and managers can begin to evaluate the social and ecological sustainability of a variety of approaches to producing edible landscapes in which gathering is an integral component. Such research has the potential to yield important lessons for cities elsewhere about whether and how to regulate or provide incentives for encouraging different types of gathering.

\section{Acknowledgments}

USDA-Forest Service, PNW Research Station (American Recovery and Reinvestment Act Funding) - The Roles of Nontimber Forest Products Gathering and Stewardship in Fostering Healthy Ecosystems in King County, WA; JVA \#: PNW 10 JV 11260489-024.

USDA-Forest Service, PNW Research Station. "Institutional Analysis of Nontimber Forest Products Gathering in Seattle, WA." JVA \# PNW 09 JV 11261975-056.

Map of Seattle designed by Christopher Walter, Cascade Land Conservancy.

\section{References}

Brody, L., Hurley, P., 2010. Gathering in the neighborhood: NTFPs in the suburbs of Philadelphia. In: Association of American Geographers. 2010 Annual Meeting, Washington D.C.

Brownlow, A., 2005. An archeology of fear and environmental change in Philadelphia. Geoforum 37 (2), 227-245.

City Fruit, 2011, http://www.cityfruit.org (retrieved 20.05.2011).

City of Seattle, 2000. Seattle Urban Forest Assessment Sustainability Matrix. Cascadia Consulting Group, Urban Forest Coalition, Seattle, http://www.seattle.gov/environment/documents/sustainability\%20matrix.pdf (retrieved 20.05.2011).

City of Seattle, 2005. City of Seattle Comprehensive Plan: Toward A Sustainable Seattle. Department of Planning and Development, Seattle http://www.seattle.gov/DPD/Planning/Seattle_s_Comprehensive_Plan/ComprehensivePlan/default.asp (retrieved 20.05.2011).

City of Seattle, 2007a. Recommendations of the Emerald City Task Force Letter to the Director of Planning and Development, December 17, 2007, Emerald City Task Force, Seattle, http://www.seattle.gov/ trees/docs/Commission_docs/Final_ECTF\%20Recs.pdf (retrieved 20.05.2011).

City of Seattle, 2007b. Urban Forest Management Plan. Urban Forest Coalition, Seattle, http://www.seattle.gov/environment/documents/Final_UFMP.pdf (retrieved 20.05.2011).

City of Seattle, 2009a. 2009-2011 City of Seattle Consolidated Plan for Housing and Community Development, Community and Population Profile, http://www. seattle.gov/humanservices/community_development/conplan/plan/default.htm (retrieved 26.05.2011).

City of Seattle, 2009b. Comprehensive Plan Amendment Replacement Pages: Environment Element. Department of Planning and Development, Seattle, http://www.seattle.gov/DPD/static/Environment\%20replacement\%202009 LatestReleased_DPDP016179.pdf (retrieved 20.05.2011).

City of Seattle, 2010a. Bridging the Gap. Department of Transportation, Seattle http://www.cityofseattle.net/transportation/BridgingtheGap.htm (retrieved 20.05.2011).

City of Seattle, 2010b. City of Seattle Launches "2010: The Year of Urban Agriculture" Campaign. City Council News Release, February 3, 2010, Seattle, http://www.seattle.gov/council/newsdetail.asp?ID=10500\&Dept=28 (retrieved 20.05.2011).

City of Seattle, 2010c. Report to the Community July 2009-June 2010 Department of Neighborhoods, Seattle, http://www.seattle.gov/neighborhoods/ news/ReportToTheCommunity2010.htm (retrieved 20.05.2011).

City of Seattle, 2010d. Seattle City Council approves urban farm and community garden legislation improving access to locally grown food. City Council News Release, August 16, 2010, Seattle, http://www.seattle.gov/ council/newsdetail.asp?ID=10996\&Dept=28 (retrieved 20.05.2011)

City of Seattle, 2010e. Seattle Permits: Street Tree Planting Procedures. Client Assistance Memo 2300. Department of Transportation, Seattle http://www.cityofseattle.net/transportation/cams/cam2300.pdf (retrieved 20.05.2011).

City of Seattle, 2010f. Seattle Street Tree Inventory. Department of Transportation, Seattle, http://www.cityofseattle.net/transportation/treeinventory.htm (retrieved 20.05.2011).

City of Seattle, 2010g. Street Tree Planting Procedures, http://www.seattle.gov/ transportation/treeswithreservations.htm (retrieved 20.05.2011).

City of Seattle, 2011a. Parks and Recreation Department, Beacon Food Forest Project Information, http://www.seattle.gov/parks/projects/jefferson/food forest.htm (retrieved 29.10.2011).

City of Seattle, 2011b. Parks and Recreation Department, Parks Urban Food Systems, http://www.seattle.gov/parks/pufs/default.htm (retrieved 20.05.2011). 
City of Seattle, 2011c. P-Patch Community Gardens. Department of Neighborhoods, Seattle, http://www.seattle.gov/neighborhoods/ppatch/aboutPpatch.htm (retrieved 20.05.2011).

Clark, J.R., Matheny, N., Cross, G., Wake, V., 1997. A model of urban forest sustainability. J. Arboric. 23 (1), 17-30.

Dooling, S., Simon, G., Yocom, K., 2006. Place-based urban ecology: a century of park planning in Seattle. Urban Ecosyst. 9 (4), 1573-1642.

Emery, M., Hurley, P., McLain, R.J., Smith, B.E., Campbell, L.K., Svendsen, E.S., 2010. Consuming nature in New York City: urban foraging as economic and ecological practice. In: Association of American Geographers. 2010 Annual Meeting, Washington D.C.

Food Research and Action Center, 2011. Food Hardship: A Closer Look At Hunger. Food Research Action Center, Washington D.C., http://frac.org/wpcontent/uploads/2011/03/food_hardship_report_mar2011.pdf (retrieved 20.05.2011).

Gobster, P.H., 2001. Visions of nature: conflict and compatibility. Landscape Urban Plan. 56, 35-51.

Green Seattle Partnership, 2006. Green Seattle Partnership 20-year Strategic Plan. Cascade Land Conservancy, Seattle, http://greenseattle. org/files/gsp20yrplan5-1-06.pdf (retrieved 20.05.2011).

Heynen, N., 2003. The scalar production of injustice within the urban forest. Antipode 35, 980-988.

Hurley, P.T., Halfacre, A., Levine, N., Burke, M., 2008. Finding a “disappearing” nontimber forest resource: using grounded visualization to explore urbanization impacts on sweetgrass basket-making in greater Mt Pleasant, SC. Prof. Geographer $60(4), 1-23$.

Jacobson, A.L., 2008. Wild Plants of Greater Seattle: A Field Guide to Native and Naturalized Plants of the Seattle Area. Arthur Lee Jacobson, Seattle.

Jahnige, P., 2002. Hidden bounty of the urban forest. In: Jones, E.T., McLain, R.J. Weigand, J. (Eds.), Nontimber Forest Products in the United States. University of Kansas Press, Lawrence, Kansas, pp. 96-107.

Klingle, M., 2007. Emerald City: An Environmental History of Seattle. Yale University Press, New Haven.

Konijnendijk, C., 2008. The Forest and the City: The Cultural Landscape of Urban Woodland. Springer Verlag, New York.

Konijnendijk, C., Gauthier, M., 2006. Urban forestry for multifunctional land use. In: van Veenhuizen, R. (Ed.), Cities Farming for the Future: Urban Agriculture for Green and Productive Cities. International Development Research Centre, Ottawa, http://www.idrc.ca/en/ev-103884-201-1-DO_TOPIC.html (retrieved 20.05.2011).

Laird, S., McLain, R., Wynberg, R. (Eds.), 2010. Wild Product Governance: Finding Policies That Work. People and Plants International Conservation Series, Earthscan, London.

Lape, P., Sheik, A., Fels, D., 2010. Waterlines Project: Discover and Explore Seattle's Past Landscapes. Burke Museum of Natural History and Culture, University of Washington, Seattle, http://www.washington.edu/burkemuseum/waterlines/ (retrieved 20.05.2011)

Lennebacker, C., 2006. Upcoming field trips. Spore Prints: Bull. Puget Sound Mycol Soc. 425 (October), $2-3$.

McLain, R., Poe, M. Hurley, P. L Lecompte-Mastenbrook, J, 2010. Greening and gathering in the Emerald City: an institutional analysis of edible landscape production in Seattle, Washington. In: Paper presented at the Association of Environmental Studies and Sciences Annual Meeting, June, Portland, OR.
Moll, G, 1989. In search of an ecological urban landscape. In: Moll, G., Ebenreck, S. (Eds.), Shading Our Cities: A Resource Guide for Urban and Community Forests. Island Press, Washington D.C., pp. 13-24.

Morgan, Brandt, 1979. Enjoying Seattle’s Parks. Greenwood Publications, Seattle, p. 224.

Nicholas, S., July 25, 2002. 'Green infrastructure' puts Seattle on the map. Seattle Daily Journal of Commerce, http://www.djc.com/news/en/11135643.html (retrieved 20.05.2011).

O'Hagan, M., July 25, 2009. Vegetable gardens crop up in Seattle's parking strips. Seattle Times, http://seattletimes.nwsource.com/ $\mathrm{html} /$ nationworld/2009535078_parkingstrips25m.html (retrieved 20.05.2011).

Pincetl, S., 2010. From the sanitary city to the sustainable city: challenges to institutionalising biogenic (nature's services) infrastructure. Local Environ. 15 (1), 43-58.

Poe, M.R., November 15, 2010. Fungi foraging in Seattle and beyond. Urban Farm Hub Website, http://www.urbanfarmhub.org/2010/11/fungi-foraging-inseattle-and-beyond/ (retrieved 20.05.2011).

Poe, M.R. 2011. Foraging Wild Foods In Urban Spaces. University of Washington, Department of Anthropology Newsletter Special Issue, http://depts.washington.edu/anthweb/enews/2011-05/urban.php (retrieved 27.05.2011).

Poe, M.R., McLain, R., Charnley, S., Hurley, P., Emery, M., Urgenson, L., LeCompteMastenbrook, J., 2011. Seattle urban foraging: a deeply interactive nature practice. In: Paper presented at the Annual Meetings of the Society for Applied Anthropology Meetings, March, Seattle.

President's Council on Sustainable Development, 1999. Towards a Sustainable America: Advancing Prosperity, Opportunity, and a Healthy Environment for the 21st Century. United States Government. Printing Office, Washington D.C., http://clinton2.nara.gov/PCSD/Publications/tsa.pdf (retrieved 20.05.2011).

Solid Ground, 2011a. Community Fruit Tree Harvest, http://www.solidground.org/Programs/Nutrition/FruitTree/Pages/default.asp (retrieved 20.05.2011).

Solid Ground, 2011b. Lettuce Link, http://www.solid-ground.org/ Programs/Nutrition/Lettuce/Pages/default.aspx (retrieved 20.05.2011).

Solid Ground, 2009. Gather It! How to Organize an Urban Fruit Harvest. Solid Ground, Seattle, http://www.solid-ground.org/ Programs/Nutrition/FruitTree/Documents/FruitHarvestHandbook8-09ONLINE.pdf (retrieved 20.05.2011).

Thomson, J., 2007. Pick wild blackberries: just don't get busted. Delicious City 1, Fall 2007, http://www.belltownmessenger.com/ deliciouscity/01-2007/012007-jess.html (retrieved 20.05.2011).

Thrush, C., 2007. Native Seattle: Histories from the Crossing-Over Place. University of Washington Press, Seattle.

Tsong, N., May 19, 2007. Urban hardwoods: unique furniture from salvaged trees. The Seattle Times, http://seattletimes.nwsource.com/html/ homegarden/2003712634_urbanhardwoods190.html (retrieved 20.05.2011).

Turner, Nancy, 1995. Food Plants of Coastal First Peoples. UBC Press, Vancouver, Canada.

U.S. Census Bureau, 2010. Profile of General Population and Housing Characteristics: 2010, http://factfinder2.census.gov/faces/tableservices/jsf/pages/ productview.xhtml?fpt=table $($ retreived 31.05.2011). 